\title{
Commentary
}

\section{THE CENTENARY OF THE BIRTH OF FREDERICK A. COOK}

\author{
John Euller
}

$\mathbf{T}$

THE YEAR 1965 will mark the passing of the 100th anniversary of the birth of Frederick A. Cook - physician, traveler, writer, and polar explorer. Cook is doubtlessly best remembered for claiming to be the first man to reach the North Pole. It is equally well remembered that the claim was quickly challenged by Robert E. Peary - naval officer, civil engineer, and also polar explorer. Peary asserted that he and not Cook had been the first to reach the Pole, and furthermore he held Cook's prior claim to be false.

Both men had strong personal motives, and the result was a bitter controversy. Each man's story had its weaknesses, but a majority of the press backed Peary. In a relentless campaign Cook was disputed, ridiculed, and in the end largely - although not unanimously - discredited.

Claim and counter-claim were made in 1909. By 1920, the year Peary died, the storm had subsided. By 1940, the year Cook died, it was all but forgotten, although the original question of who had been first at the Pole was never really resolved. Meanwhile a sizeable literature has developed and continues to grow, new facts have come to light, and Cook's cause continues to find support among a small number of sceptics who seek a true verdict in place of what some feel was a decision forced by newspaper propaganda.

Dr. Cook's 100th anniversary is a fitting occasion for a review of the evidence and a restatement of the case. The recognition of Cook's personal achievement is at stake, but a larger issue is to determine - if possible history as it really was and not as some might wish it to have been. The essential requirement - indeed, the only requirement, if justice is to be done - is to restrict the discussion to the pertinent facts and their logical interpretation. Hearsay, pseudo-scientific testimonials, and evidence not directly related to the case should be rejected, although these three categories account for many hundreds of thousands of words in the published literature. From this stringently defined base at least seven arguments emerge that support the view that it was not only possible but very probable that in April 1908 Cook was the first man to reach the North Pole. 
1. Feasibility of method. As Peary, Cook adopted Eskimo methods of travel; if they differed in any way, Cook's technique was superior. He used lighter sledges, a smaller party, and lived in part off the land. He was 43 years old, in excellent physical condition, and experienced in polar travel and living. Thus endowed, the journey to the Pole was for him perfectly feasible.

2. Proven ability. Cook's base was at Annoatok in Greenland. From here he traveled to Cape Stallworthy at the northern tip of Axel Heiberg Island, and from this point he started his journey across the polar ice. He planned to return by roughly the same route, but he was carried off course by drifting ice. He returned to land much farther south than he expected and the consequent delay forced him to spend the winter at Cape Hardy on Devon Island. The following spring he sledged back to Annoatok and thence south to Upernavik where he met a Danish ship. The total distance travelled was approximately 2,680 nautical miles. The part of the journey between Annoatok and Cape Stallworthy and the return from the first landfall in the Sverdrup Islands to Upernavik amounts to some 1,640 miles. That Cook made this part of the total journey and that he therefore had the necessary ability for sustained, long-distance arctic travel has never been doubted. It was thus well within his ability to travel the additional 1,040 miles from Cape Stallworthy to the Pole and return.

3. Original descriptions. At the time of Cook's journey no one had ever before seen the region that lies close to the North Pole. When Cook returned he described what he had seen: no land, a continuation of the polar ice pack, essentially a frozen ocean but in a state of continuous motion and upheaval. This was not profound, but it was original, and all subsequent accounts, including Peary's, agree with Cook's original descriptions.

4. Unknown westerly drift. When returning south from the Pole heavy overcast forced Cook to navigate by dead reckoning. He laid his course to take into account what he thought to be a slight eastward drift of the ice. It was not then known that in the region where Cook traveled, the ice drifts towards the west. Cook was thus carried 100 miles west of his expected landfall, and the consequent delay, already mentioned, forced him to winter at Cape Hardy. Cook could not have invented or anticipated this drift; the error caused by it lends great credibility to his account of the journey. Furthermore, the amount of the offset suggests that he began his return journey at a point north of the Queen Elizabeth Islands.

5. Ice islands. In $88^{\circ} \mathrm{N}$. Cook saw an unusual ice feature: a flat-topped mass of ice, higher and therefore thicker than ordinary sea ice, and with an upper surface marked by undulations or waves. What Cook had discovered was an ice island, one of the tabular masses of ice that are now known to have their origin in the ice shelves that rim parts of the northern coast of Ellesmere Island. The ice islands are known to drift in the area of the Arctic Ocean between Alaska and the North Pole in a slow clockwise motion, moving southward along the west side of the Queen Elizabeth Islands. The discovery was incidental to Cook's main purpose and was forgotten until 40 years later when the ice islands were rediscovered during 
an aerial reconnaissance, but again we have something Cook could not have invented and his account gains credibility from it.

6. Bradley Land. When marching across the ice Cook saw in $85^{\circ} \mathrm{N}$. what he thought to be land, far distant and to the west. He named it Bradley Land in honor of his benefactor. Curiously, two years before Peary had made a similar discovery, roughly 150 miles to the south. Neither man could possibly strengthen his claim to the Pole by falsely reporting the discovery of land; yet neither Bradley Land nor Peary's Crocker Land was ever seen again. Were both men liars? A more plausible explanation is that both had sighted an ice island, possibly the same one, but higher and more massive than Cook's first discovery. The 150-mile distance between the two sightings does not contradict the observed drift of present day ice islands. Ironically the two rivals corroborate each other.

7. A consistent narrative. Cook's published account of his journey to the Pole has never been seriously refuted on the basis of internal evidence. This in itself it not remarkable, since he was its sole author and had ample time to prepare it. But in the 50 years that have passed since it was written, the external evidence cited above has come to light. Cook could not have invented his accurate descriptions of the north polar region, of ice islands, or contrived to have himself set off course by an undiscovered drift. This becomes an argument in itself. How were all these circumstances incorporated into his account? It is the final and perhaps strongest argument for its authenticity.

To summarize the main points: a feasible method of travel, a proven ability to make extended arctic journeys, the first correct descriptions of the area around the North Pole, discovery of a westerly drift of the ice northwest of the Canadian Arctic Archipelago, discovery and accurate description of ice islands, corroboration by Peary in the matter of Bradley and Crocker Lands, and a logical narrative consistent with external ex post facto evidence.

Has the case been proved? The answer is still no. The exploits of Cook and Peary were long, lone journeys over moving ice; no monuments could be erected, no competent witness accompanied either man. Neither man's claim is subject to positive proof - and never will be. Each man's claim must rest on his word and on the logical consistency of his story supported by whatever external evidence can be adduced. The case for Cook is strong and should be reviewed by fair-minded men.

At Dr. Cook's 100th anniversary it is perhaps late to seek a restoration of his claim - but it is not too late. The editor of his last book said this about the explorer: "His tragedy paralleled that of Columbus. He was rejected, despised . . . and neglected. Columbus turned to divine support; Dr. Cook relied on the innate sense of justice in men . ..." 